\title{
DOES PROACTIVE PERSONALITY MATTER IN LEADERSHIP TRANSITIONS? EFFECTS OF PROACTIVE PERSONALITY ON NEW LEADER IDENTIFICATION AND RESPONSES TO NEW LEADERS AND THEIR CHANGE AGENDAS
}

\author{
WING LAM \\ The Hong Kong Polytechnic University \\ CYNTHIA LEE \\ Northeastern University \\ M. SUSAN TAYLOR \\ University of Maryland \\ HELEN H. ZHAO \\ The University of Hong Kong
}

\begin{abstract}
Despite the growing frequency of leadership transitions and their significant impact on team and organizational performance, little research has examined why and how teams develop identification with a new leader, or their subsequent receptiveness to the new leader's change initiatives. Drawing from the contrast and congruence effects and the theoretical perspectives of leader identification, this study empirically tests a model in which the congruence of new leaders' and their teams' proactive personalities foster new leader identification, as well as the team's behavioral responses to the new leader's change agenda. This effect is strongest when the new leader's proactive personality is higher than that of the former leader's proactive personality (positive contrast). Our findings of a four-wave "before-and-after" transition survey of 155 hotel employees and 51 new leaders, achieved through polynomial regression analyses, proved very insightful. We found that the congruence between a new leader's and his or her team's proactive personalities, and the positive contrast between a former leader's and the new leader's proactive personalities, enhanced new leader identification and the team's shared identification with the new leader's change agenda, and thereby led the team to exhibit more behavioral engagement with, and voice behavior about, the new leader's change agenda.
\end{abstract}

Modern organizations implement leadership transitions or changes in management on a regular basis (Neff \& Citrin, 2005). New leaders often face a challenging task when they take charge of their

We are grateful to Prof. Daan van Knippenberg and three anonymous reviewers for their constructive and detailed comments during the revision process. We also thank Prof. Jason Shaw, Dr. Zhen Zhang, and Prof. Mo Wang for their insightful feedback on previous drafts. This research was supported by grants from the Research Grant Council of the Hong Kong Special Administrative Region, China (GRF no. 155036/14B) and PolyU Central Research Grant (no. G-YN72, $5941 / 13 H)$. In closing, the authors most gratefully acknowledge the valuable assistance of Prof. Jeff Edwards and his advice on polynomial regression analysis and response surface modeling analyses for this article. new roles, in the midst of team members' reactions to the transition. According to Watkins (2009), $87 \%$ of 143 human resource professionals reported that transitions into significant new roles are the most challenging events or times in the professional lives of managers, because the transitions affect team members' attitudinal and behavioral reactions.

Although much has been written on CEO and top management transitions (e.g., Ang, Lauterbach, \& Vu, 2003; Ballinger \& Marcel, 2010; Cannella \& Shen, 2001; Giambatista, Rowe, \& Riza, 2005; Graffin, Boivie, \& Carpenter, 2013; Graffin, Carpenter, \& Boivie, 2011; Huson, Malatesta, \& Parrino, 2004; Shen \& Cannella, 2002, 2003; Zhang, 2008; Zhang \& Rajagopalan, 2003), little attention has centered on leader transitions at middle management or lower 
levels of the organization (e.g., Ballinger \& Schoorman, 2007; Ballinger, Schoorman, \& Lehman, 2009; Sauer, 2011). This omission is significant, because middle- or lower-level managers are psychologically and physically closer to employees in the organization's day-today operations than are CEOs and top management, and they actually implement the policies that shape employees' daily performance (Huy, 2002). Therefore, understanding how new leaders at lower levels of the organization obtain team members' acceptance of their change goals is key to the success of change events.

Researchers have also argued that the success of leadership transitions depends on the personal attributes of new leaders, such as their ability, history, status, directive or participative leadership styles, and charismatic or transformational leadership approaches (e.g., Ballinger \& Schoorman, 2007; Ballinger et al., 2009; Lester, Meglino, \& Korsgaard, 2002; Sauer, 2011; Zhao, Seibert, Taylor, Lee, \& Lam, 2016), which can affect employee and team performance. However, new leaders do not operate in a historic vacuum, so these attributes get measured against the personal attributes of their predecessors. Evidence has affirmed that employees' reactions to a new leader are influenced by the leader's contrast with the former leader, who previously left the unit (Zhao et al., 2016). Employees rely on their stored impressions of their former leader to assist them in developing their reactions to their new leader (Ritter \& Lord, 2007; Srull \& Wyer, 1989) before they initiate, act, or engage in organizational changes, especially during a leadership transition. Similarly, new leaders do not operate in a social vacuum, so when their personal attributes are quite congruent with those of the team, this congruence may create positive synergies that encourage the team's receptiveness to the new leader's change initiatives.

Such change initiatives are likely to emerge after a managerial transition, and leader transitions present opportunities for change, with some changes being expected to occur within 90 days (Watkins, 2003). Proactive people in particular seize opportunities to enact behaviors that can drive a change agenda (Watkins, 2009). The resulting proactive behaviors are "self-initiated futureoriented actions that aim to change and improve the situation or oneself" (Parker, Williams, \& Turner, 2006: 636), including work processes in the internal organizational environment. These behaviors are shaped by individuals' proactive personalities, which are relatively unconstrained by situational forces and effect environmental change (Bateman \& Crant, 1993). Interestingly, people with highly proactive personalities do not simply react to the environment but instead "scan for opportunities, show initiative, take action, and persevere until they reach closure by bringing about change" (Bateman \& Crant, 1993: 105). In change contexts, such as those created by middle and lower managers' transitions, we need a clearer understanding of the contrast between the proactive personality of the former and new leaders, as well as the congruence resulting from the proactive personality of the new leader and his or her team. We believe that, together, both contrast and congruence elements serve to create a sense of leader identification and the team's receptivity to the transition.

Specifically, leader identification occurs when the team's beliefs or values coincide with those of the leader (Kark, Shamir, \& Chen, 2003), whose beliefs originate with members' self-concepts, values, and personality. When a highly proactive new leader is paired with teams whose members are also high in proactivity, they likely "sync" with one another, and stimulate a set of shared norms, values, and oneness that leads to greater identification with the new leader. We further argue that this congruence effect on leader identification will be strengthened by a greater positive contrast between the new leader and the former leader. For, as noted above, new leaders tend to be measured against the personality of their predecessors, thereby either hindering or enhancing the development of shared norms between the new leader and the team. By examining the mediating role of leader identification in the proactive personality and proactive behavior relationships, we extend several established theoretical perspectives.

Specifically, our study contributes to the proactivity and leader transition literatures in several ways. First, as stated earlier, prior studies of leadership transitions have typically examined the effects of leader attributes but have not examined contrast effects that emerge from comparison of the former leader's and the new leader's proactive personalities. Nor have prior studies examined the congruence effect between new leaders' and their teams' proactive personalities, despite its potentially positive influence on teams' proactive behaviors during the transition (e.g., Ballinger \& Schoorman, 2007; Ballinger et al., 2009; Sauer, 2011). Exploring these effects will yield interesting findings and avenues for research on leader transition. Second, we extend a theoretical framework regarding proactive personalities and proactive behavior, using a leader identification perspective. Various theoretical explanations have been advanced to understand the proactive personality and 
proactive behavior relationships, but without noting leader identification or the team's shared identification with its leader. For example, Li, Liang, and Crant (2010) and Zhang, Wang, and Shi (2012) proposed a progressive, relational approach represented by the leader-member exchange (LMX) as a mediator, while other researchers have suggested motivational approaches such as job search efficacy (Brown, Cober, Kane, Levy, \& Shalhoop, 2006), motivation to learn (Major, Turner, \& Fletcher, 2006), and a social capital perspective (Thompson, 2005). Therefore, we add to extant theory by integrating the contrast and congruence perspectives, and we examine leader identification as another theoretical explanation for the relationship between a proactive personality and proactive behavior. Third, we improve prior research that has largely relied on either experimental or correlational designs focusing on employee perceptions after the new leader's entrance (e.g., Ballinger et al., 2009; Sauer, 2011) by adopting a "before-and-after" transition research design. In doing so, we first accessed the former leader's own rating of his or her proactive personality before the transition. After the leader transition, new leaders and team members rated their own proactive personalities. Thus, we contribute to the scant literature on leader transition by improving the research design and providing empirical evidence of the contrast effect between the former and the new leader in the context of leader transition research.

\section{THEORETICAL BACKGROUND AND HYPOTHESES DEVELOPMENT}

As new leaders arrive, often with their change goals and agenda in mind, employees may engage cognitively and emotionally with the new leader's mission. However, this depends on their comparisons and evaluations of the new leader relative to the former leader. Zhang et al. (2012) acknowledged the importance of congruence between leader and employee proactivity; because leaders are responsible for developing goals for team members, the leader and his or her team member's congruent proactive personalities can motivate team members to attain their goals. Therefore, rather than focusing on either the leader's or the team's proactive personalities separately, we investigate the congruence between these two parties, as well as the norms and values responsible for the new leader's identification. We note that new leader identification subsequently effects the team's engagement with the new leader's change agenda, and its willingness to speak up and provide voice about the change.
In our study, leader identification refers to the value and emotional significance attached to the new leader and the new leader's change agenda (see van Knippenberg, van Knippenberg, De Cremer, \& Hogg, 2004). These two forms of new leader identification are related but distinct: One is directed toward the new leader as a person, whereas the other pertains to the change agenda proposed by this new leader. Even if a team identifies with the new leader, it does not necessarily identify with the proposed agenda, or vice versa. Together, they provide a more complete picture, reflecting both the person and the task.

New leader identification is an aggregate of team members' personal identification with the new leader; it captures a high level of identification across the team, instead of individual heterogeneity. According to Hobman, Jackson, Jimmieson, and Martin (2011) and van Knippenberg et al. (2004), identification with a significant other (i.e., the new leader in our study) determines the extent to which team members define themselves in terms of the attributes of the leader, shifting their focus to the leader's interest as a shared interest, and experiencing a high level of connection with the leader. When the new leader arrives, different ways of doing things emerge, activating the self-concepts of team members (Andersen \& Chen, 2002; Demo, 1992; Markus \& Wurf, 1987). If the new leader and the team match in their proactive personalities, the distance between them, as well as that of the new leader's change agenda, becomes smaller. Therefore, the overlap of their shared identity becomes higher. Thus, we posit that congruent proactive personalities lead to new leader identification and, subsequently, to the team's behavioral effects on the new leader's change agenda.

We also apply a contrast-based theoretical lens to explain how new leader identification forms during leader transition. The theoretical rationale for contrast effects is straightforward: People live in their past experiences (Markman \& McMullen, 2003; Tversky \& Griffin, 1991), and therefore this affects the criteria they use to evaluate the present. Yet a positive past makes the positive present seem less impressive, while a negative past makes the same positive present feel more positive (Schwarz \& Bless, 1992). Social psychology researchers have often used the example of a prisoner to explain this contrast effect (see Frederick \& Loewenstein, 1999): A prisoner placed in a nine-foot cell might be happy if the previous cell that housed him or her was only seven feet, whereas another prisoner in the same cell could be depressed if previously this person was free 
of any prison setting. Thus, the application of different standards leads to different reactions regardless of whether the individuals experience the same setting.

A new leader transition also activates a contrast process of the positive past and positive present or the negative past and positive present. At the moment of transition, mental representations of both the former leader and the new leader are accessible to team members. One has just transitioned out from the team and the other has transitioned into it, so the comparison information of these two leaders are accessible for employees (Ritter \& Lord, 2007; Sauer, 2011). Team members tend to compare the attributes of the former leader, who serves as the standard for comparison, with those of the new leader, who may constitute new stimuli. We expect two forms of contrast effects in this case. On the one hand, a negative contrast (stronger positive past and weaker positive present) might arise, such that the higher the former leader's proactive personality is found to be, and the more positive the former leader is relative to the new leader, the more the contrast effects produce judgments that are less positive toward the new leader, reflecting the very high standard for comparison. On the other hand, a positive contrast (weaker positive past and stronger positive present) is possible too. The lower the former leader's proactive personality is compared with the new leader's, the more the contrast effects should yield judgments that are more positive for the new leader (Schwarz \& Bless, 1992; Van den Bos et al., 2005).

If the new leader's proactive personality is stronger than the former leader's, a positive contrast should arise, such that the team may be more likely to identify with the new leader and help this leader develop and enact his or her change agenda. However, if the new leader's proactive personality is weaker than the former leader's, due to the negative contrast the team is less likely to identify with the new leader. Therefore, the leader contrast moderates the effect of congruence on leader identification. Thus, we hypothesize:

Hypothesis 1. The contrast between the proactive personalities of the former leader and the new leader moderates the relationship of the congruence between the new leader's and the team's proactive personalities and the team's shared identification with (a) the new leader and (b) the new leader's change agenda. A positive contrast strengthens the relationship; a negative contrast weakens it.

\section{Mediating Roles of Team's Shared Identification with their New Leader and His or Her Change Agenda}

Leadership transitions may be short-term organizational phenomena but still can have significant, long-lasting impacts on organizational practices and survival (Watkins, 2003). Thus, we consider it practically relevant and theoretically important to assess when and why teams identify with their new leader and exhibit behavioral responses related to their new leader's change agenda. A successful leadership transition requires high degrees of the leader's identification, such that the team members define themselves in terms of the attributes of shifting their focus to that of the leader's interest as a shared interest and experiencing a high level of connection with both the new leader and his or her change agenda.

When the proactive personalities of both the new leader and the team are high, these two parties tend to act proactively, seeking out opportunities to improve their existing work conditions. As a result, the teams will likely invest effort in support of the new leader and his or her change agenda. Leader identification should mediate the moderating effect of the contrast between the new and the former leaders' proactive personalities and teams' behavioral responses to the new leaders' change agendas. Consistent with the discretionary change implementation behavior predicted by Herscovitch and Meyer (2002), we identify two behavioral responses to a leadership transition: (1) teams' engagement with the leader's change agenda, and (2) teams' voice or speaking-out behavior directed toward the change agenda.

Similar to the concept of job engagement (Kahn, 1990; Rich, Lepine, \& Crawford, 2010), our conceptualization of engagement behavior involves the team's implementation of a leader's change agenda and strong persistence, even when difficulties arise. The act of speaking out about a new leader's change agenda is particularly important. That is, a successful organizational change requires teams to take the initiative to improve current work situations, consistent with the spirit and objectives of the underlying change (Fugate \& Kinicki, 2008). Therefore, teams cannot be passive recipients of the uncertain environmental constraints produced by organizational change, especially due to the unpredictability and uncertainty associated with leader transitions (Seo, Taylor, Hill, Zhang, Tesluk, \& Lorinkova, 2012; Shin, Taylor, \& Seo, 2012). Rather, teams should 
proactively engage with and speak out about their concerns by challenging the status quo and providing constructive suggestions for their new leader's change agenda.

When people are emotionally attached, whether to a significant other or an organization, they develop positive attitudinal and behavioral responses (see van Knippenberg et al., 2004). Thus, new leader identification and his or her change agenda should motivate teams to take the leader's interest to heart and thereby contribute positive behavioral responses (see van Knippenberg et al., 2004). In a leadership transition, new leader's identification will cause the team to view change goals and actions positively and to be more willing to move the new leader's change agenda forward by engaging with those agendas and speaking out about them. The teams' effects may prove even more instrumental when the proactive personalities of new and former leaders are incongruent in their levels. Therefore, we predict a mediated moderation, as in the following hypotheses:

Hypothesis 2. New leader identification, an aggregate of a team's personal identification with the new leader, mediates the relationship of the congruence between the new leader's and the team's proactive personalities with the team's (a) engagement with and (b) voice about the change agenda. The mediation effect is stronger when the former leader-new leader contrast is positive rather than negative.

Hypothesis 3. New leader identification, an aggregate of a team's personal identification with the new leader's change agenda, mediates the relationship of the congruence between the new leader's and the team's proactive personalities with the team's (a) engagement with and (b) voice about the change agenda. The mediation effect is stronger when the former leader-new leader contrast is positive rather than negative.

\section{METHODS}

\section{Sample and Data Collection}

The study sample included 155 hotel employees and their 51 newly encountered direct low- to middle-level managers from the hospitality industry in mainland China. We chose to focus on the hospitality industry because leadership transitions are common in this industry and invoke disruptive outcomes for both hotels and their employees
(Lam \& Chen, 2011). China's hospitality industry is also developing at a rapid pace, according to the 2015 Annual Report of China Inbound Tourism Development. According to the China Tourism Academy, in 2015, China was expected to receive more than 4 billion visitors (1.3 billion international), generating U.S.\$550 billion in income through the hospitality industry. Assuming such growth has continued, it is likely that demand for hotels will increase. Our data were collected across a large limited corporation, the second-largest hotel group in China and the largest private, upscale hotel chain in China. As of August 2015, this hotel group owned and managed more than 160 hotels that provided more than 50,000 guest rooms, spread across different cities in China. The group has a reputation for good customer service, aims to provide high-quality and upscale hospitality services, and is facing a rapidly changing environment.

According to our personal interviews with the human resource director, similar to other wellknown international hotels, this hotel group views lower- to middle-levels managers as valuable assets, who move information received from customers up the hierarchy for the purpose of continuous improvement. Higher-level managers accordingly delegate authority to lower-level managers to establish new work operations, procedures, and systems. To ensure that the new leaders we investigated had not been assigned a change agenda by upper management, we also interviewed the human resource director and associate director, together with 32 low- to middle-level managers. On the basis of these interviews, we developed six items to ask new leaders and team members whether the newly transitioned leaders had established change agendas in six key areas, such as "Re-arrange and assign work roles or duties (e.g., assign new work roles or duties to team members)" $(0=$ no; $1=$ yes $)$. The mean scores for the new leaders' change agendas, as rated by 223 team members at Time 1 (immediately after the leadership transition) was .67 (ranging from .33 to 1). Thus, team members perceived change agendas from their new leaders. We excluded cases with a mean score of 0 for the six items, because in these cases the new leader did not issue any change agenda.

In this ideal context for studying leadership transitions and intense change agendas, after taking the preceding measures, we decided to begin our first wave of data collection before the Chinese New Year, when the organization typically undergoes a largescale leadership transition, which enhanced our chances of securing an adequate sample for the 
study. Our "before-and-after" design featured a timelagged survey questionnaire that we used to test the research model. We asked the human resources department of the company to invite 420 randomly chosen employees and their 155 direct managers (i.e., potential former leaders) to participate in the first wave of data collection (Time 0 , before transition). Then, for Time 1, we included a question that asked employees whether they had experienced a recent transition in their low- to middle-level managers. Overall, the time-lagged data were collected with two-month intervals in 2015: January (Time 0, before transition), March (Time 1, after transition), May (Time 2), and July (Time 3). Experienced hotel staff members and managers reported that two-month time lags were sufficient to allow respondents to identify with their new leaders and display the change behaviors measured in the study.

The survey was administered in several large rooms (with leaders and employees in separate rooms, located on different floors) in the hotels at different times, according to the respondents' break times. The respondents received a cover letter explaining the study, a questionnaire, and a return envelope. The cover page assured the confidentiality of all data that the respondents provided the researchers and informed them that the information was for research purposes only. Each questionnaire was coded with a researcher-assigned identification number, to match employees' responses with their immediate leaders' evaluations. In addition, to ensure confidentiality, respondents were instructed to seal the completed questionnaires in the envelopes and return them directly to the researchers on site.

Our initial sample size at Time 0 (before transition) was 420 employees from 155 work teams. The sample size at Time 1 (after transition) was $223 \mathrm{em}$ ployees from 87 work teams (attrition rates of $46.90 \%$ and $43.87 \%$ for the team and leader respondents, respectively). We considered these attrition rates acceptable for the research context, which explicitly focused on leadership transition. Thus, the high attrition rates at Time 1 indicated that even though they had been expected to do so, some participants did not undergo a leadership transition process after Time 0. Furthermore, a few teams did not recognize new leaders' change agendas, and some respondents left the hotels after the transitions.

At Time 2, the sample size consisted of $174 \mathrm{em}-$ ployees nested within 63 work teams, for attrition rates of $27.59 \%$ and $21.97 \%$, respectively, in accordance with a normal attrition rate of approximately $30 \%$ at each stage in a time-lagged design (Goodman
\& Blum, 1996). The final sample was 155 employees from 51 work teams with an average team size of 3.04 at Time 3 (approximately six months after the transition). These attrition rates were $19.05 \%$ and $11.49 \%$, respectively. To determine whether subject attrition created any detectable differences in our sample, we conducted a multivariate analysis of variance to compare four subject groups (Lance, Vandenberg, \& Self, 2000): (1) group 1 completed all four waves ( $n=155$ ); (2) group 2 completed the first three waves but not the fourth $(n=19)$; (3) group 3 completed the first two waves but not the last two waves ( $n=49)$; and (4) group 4 completed the first wave only $(n=197)$. The results showed that these four groups were invariant in terms of employee age, gender, and educational level. The four groups did not exhibit different team proactive personality levels in wave 1; therefore, there was no evidence that our final sample suffered from attrition bias.

For the final employee sample, the mean age was 29.57 years (ranging from 18 to 53 years), the mean job tenure was 3.37 years, and the average educational level was a vocational college degree. For the final new leader sample, the mean age was 33.05 years (ranging from 20 to 58 years), the mean job tenure was 3.81 years, and the average educational level was a university degree. Within the former leader sample, the mean age was 29.77 years (ranging from 21 to 46 years), the mean job tenure was 3.87 years, and the average educational level was a university degree. The average time lag following the transition, reported at Time 1 , was 6.82 weeks (ranging from 1 to 10 weeks). The average transition time between the former and new leaders was 3.97 days (ranging from 0 to 15 days).

\section{Measures}

We collected data from three independent sources, such that we used three separate sets of questionnaires for individual team members, their former leaders, and their newly appointed leaders. The team member survey asked participants to self-report their demographic characteristics (at Time 0), proactive personality (at Time 1), new leader identification (at Time 2), and team's shared identification with the new leader's change agenda (at Time 2). The former leader survey requested that they provide ratings of their own proactive personality (at Time 0), along with demographic variables. We asked the new leaders to rate their own proactive personalities (at Time 1), demographic variables, and team members' engagement with and voice behavior toward their 
change agenda (at Time 3). A double-blind backtranslation (Brislin, Lonner, \& Thorndike, 1973) method served to translate the items from English to Chinese. All measures used a Likert response scale ranging from 1 (strongly disagree) to 7 (strongly agree).

Proactive personality. We assessed former leaders', new leaders', and team members' proactive personalities using 10 items from Seibert, Kraimer, and Crant's (2001) short version of the proactive personality measure, validated according to Bateman and Crant's (1993) original 17 items. A sample item for employee self-report assessment was: "I am always looking for better ways to do things." For team proactive personality, we followed prior research and used a direct consensus composition model (Chan, 1998; Cole, Carter, \& Zhang, 2013) when accessing members' responses. The data were aggregated to represent a team construct. The Cronbach's alphas were $.86, .80$, and .86 for the former leader's, new leader's, and team's proactive personalities, respectively.

New leader identification. We assessed new leader identification using the seven-item scale developed by Shamir, Zakay, Breinin, and Popper (1998). Sample items were "My leader represents values that are important to me," and "My leader is a model for me to follow." The data were aggregated to represent a team construct. The $\alpha$ coefficient of this measure was .92.

Team member's shared identification with the new leader's change agenda. We adopted and modified Herscovitch and Meyer's (2002) six-item affective commitment to change scale to assess team members' shared identification with the new leader's change agenda, because it directly specifies an organization change context and has been validated (Seo et al., 2012). We modified the wording to fit our research domain related to the new leader's change agenda. A sample item was "His or her change agenda is good for our work team” ( $\alpha=.89)$. The data were aggregated to represent a team construct.

Team engagement with the new leader's change agenda. We adopted four items from Rich and colleagues (2010), which focused on the physical aspects of job engagement. We intentionally excluded emotional and cognitive aspects from this engagement scale, because those two aspects largely reflect teams' feelings and perceptions of identification with the new leaders and their change agendas, which might overlap with our mediator variables. We modified the wording of the engagement scale to fit the study domain, such as "This employee has exerted his or her full effort to his or her tasks in the change agenda I have set for the work team." The data were aggregated to represent a team construct. The $\alpha$ coefficient is .88.

Team member's voice behavior about the new leader's change agenda. We modified Van Dyne and LePine's (1998) six-item measure of voice to refer to the new leader's change agenda, such as "This employee defends programs in my [new leader's] change agenda that are worthwhile when others unfairly criticize the programs." The data were aggregated to represent a team construct. The $\alpha$ coefficient is .94.

Control variables. Following previous studies on leader transition (e.g., Huson et al., 2004), we controlled for demographic characteristics, including gender, age, education level, organizational tenure, and team size, that might systematically affect the data analyses and results. We also controlled for LMX using a measure provided by team members, because prior research has indicated effects of leader-employee similarity in terms of proactive personality on LMX (Zhang et al., 2012). Finally, we controlled for the amount of time since the transition, because it might take time for the identification variable to become effective.

\section{Data Aggregation}

A corresponding analysis of variance demonstrated that team proactive personality, $F(50,104)=$ 1.77, $p<.01$; new leader identification, $F(50,104)=$ $1.89, p<.01$; team's shared identification with the new leader's change agenda, $F(50,104)=1.67$, $p<.01$; team engagement with the change agenda, $F(50,104)=5.28, p<.001$; and team voice behavior about the change agenda, $F(50,104)=7.92, p<.001$ all differed significantly across teams. The intraclass correlations (ICC1) for these five variables were $.20, .23, .18, .59$, and .69 , respectively; the ICC2 values were $.44, .47, .40, .81$, and .87 , respectively. The indicators reveal high, between-team variance and within-team agreement in these five variables (see, Bliese, 2000).

\section{RESULTS}

\section{Preliminary Analyses}

Confirmatory factor analyses. Before testing the hypotheses, we conducted a series of confirmatory factor analyses (CFAs) to evaluate the discriminant 
validity of the variables in AMOS 22. We conducted the CFAs after forming item parcels for each construct. First, all the constructs are unidimensional (e.g., Herscovitch \& Meyer, 2002; Rich et al., 2010; Seibert et al., 2001; Shamir et al., 1998; Van Dyne \& LePine, 1998), so the chance of concealing a multidimensional factor structure and producing biased structural parameter estimates is very low (Bandalos, 2002; Bandalos \& Finney, 2001). Rather, the constructs were modeled with parcels, each using two to three randomly assigned items. Second, the ratio of subject-to-item would be too low (2.5:1) if we used all the original items (51 work teams)—far below the ideal ratio of 10:1 and even lower than the acceptable lower bound limit of 5:1 (Bandalos, 2002). To reduce the number of parameters in the analysis and keep the degree of freedom reasonable, we used an itemparceling method recommended by Bagozzi and Edwards (1998) to conduct the CFAs.

We conducted a CFA for the two mediators (i.e., new leader identification and team's shared identification with new leader's change agenda) and the team's proactive personality rated by team members. The results suggested that the three-factor model $\left(\chi^{2}=58.51, d f=41\right.$, confirmatory fit index $[\mathrm{CFI}]=.98$, Tucker-Lewis index $[\mathrm{TLI}]=.98$, root mean square error of approximation [RMSEA] = .05) yielded a better fit than any alternative models. Next, we conducted another CFA for the two dependent variables (i.e., engagement with change agenda and voice behavior toward the change agenda) and the new leader's proactive personality, as reported by the new leaders. The result suggested that the three-factor model $\left(\chi^{2}=56.64\right.$, $d f=30, \mathrm{CFI}=.98, \mathrm{TLI}=.96, \mathrm{RMSEA}=.08)$ yielded a better fit than alternative models. The results of the CFAs also confirmed that the constructs were distinguishable.

Descriptive statistics. Table 1 presents the means, standard deviations, and zero-order Pearson correlations of all the variables.

\section{Hypotheses Tests}

We used polynomial regression (Jansen \& KristofBrown, 2005) and response surface modeling analyses (Edwards, 2002; J. R. Edwards, personal communication, 2016; Edwards \& Parry, 1993) to test our congruence hypotheses (see Figure 1). For these analyses, we estimated quadratic regression equations, using a measure of new leader identification (ID) and team's shared identification with the new leader's change agenda (IDCA) as the dependent variables; the team's proactive personality $(T)$ and new leader's proactive personality $(N)$ as the independent variables; incongruence between new and former leaders' proactive personalities $(N-F)$ as the moderator; and quadratic terms constructed from these measures. The general expression was:

$$
\begin{aligned}
\text { ID or IDCA }= & \mathrm{b}_{0}+\mathrm{b}_{1} T+\mathrm{b}_{2} N+\mathrm{b}_{3} T^{2}+\mathrm{b}_{4} T N \\
& +\mathrm{b}_{5} N^{2}+\mathrm{b}_{6} F+\mathrm{b}_{7} T F+\mathrm{b}_{8} N F \\
& +\mathrm{b}_{9} T^{2} N+\mathrm{b}_{10} T^{2} F+\mathrm{b}_{11} T N^{2} \\
& +\mathrm{b}_{12} T N F+\mathrm{b}_{13} N^{3}+\mathrm{b}_{14} N^{2} F+\mathrm{e} .
\end{aligned}
$$

Following Edwards and colleagues' procedures for performing moderated polynomial regressions (Edwards, 2002; J. R. Edwards, personal communication, 2016; Edwards \& Parry, 1993), in the first step we regressed the dependent variables (i.e., new leader identification, team's shared identification with the new leader's change agenda) on the control variables. In the second step, we added five polynomial terms (i.e., $T, N, T^{2}, T \times N, N^{2}$ ). Then, in the third step, we added the former leader's proactive personality $(F)$. Finally, we added eight moderated polynomial terms:

(1) Team's proactive personality times former leader's proactive personality $(T \times F)$.

(2) New leader's proactive personality times former leader's proactive personality $(N \times F)$.

(3) Team's proactive personality squared times new leader's proactive personality $\left(T^{2} \times N\right)$.

(4) Team's proactive personality squared times former leader's proactive personality $\left(T^{2} \times F\right)$.

(5) Team's proactive personality times new leader's proactive personality squared $\left(T \times N^{2}\right)$.

(6) Team's proactive personality times new leader's proactive personality times former leader's proactive personality $(T \times N \times F)$

(7) New leader's proactive personality cubed $\left(N^{3}\right)$.

(8) New leader's proactive personality squared times former leader's proactive personality $\left(N^{2} \times F\right)$.

As Table 2 indicates, the increments in the R-square values associated with the $b_{7}-b_{14}$ terms (ID $\Delta R^{2}=.16$, $p<.001$; IDCA $\Delta R^{2}=.11, p<.001$ ) were statistically significant, in support of moderation effects.

To confirm that these moderating effects were consistent with our hypotheses, we again followed Edwards' procedures and plotted the surface, one standard deviation below and above the mean of the moderator (Edwards, 2002; J. R. Edwards, personal communication, 2016; Edwards \& Parry, 1993), as 


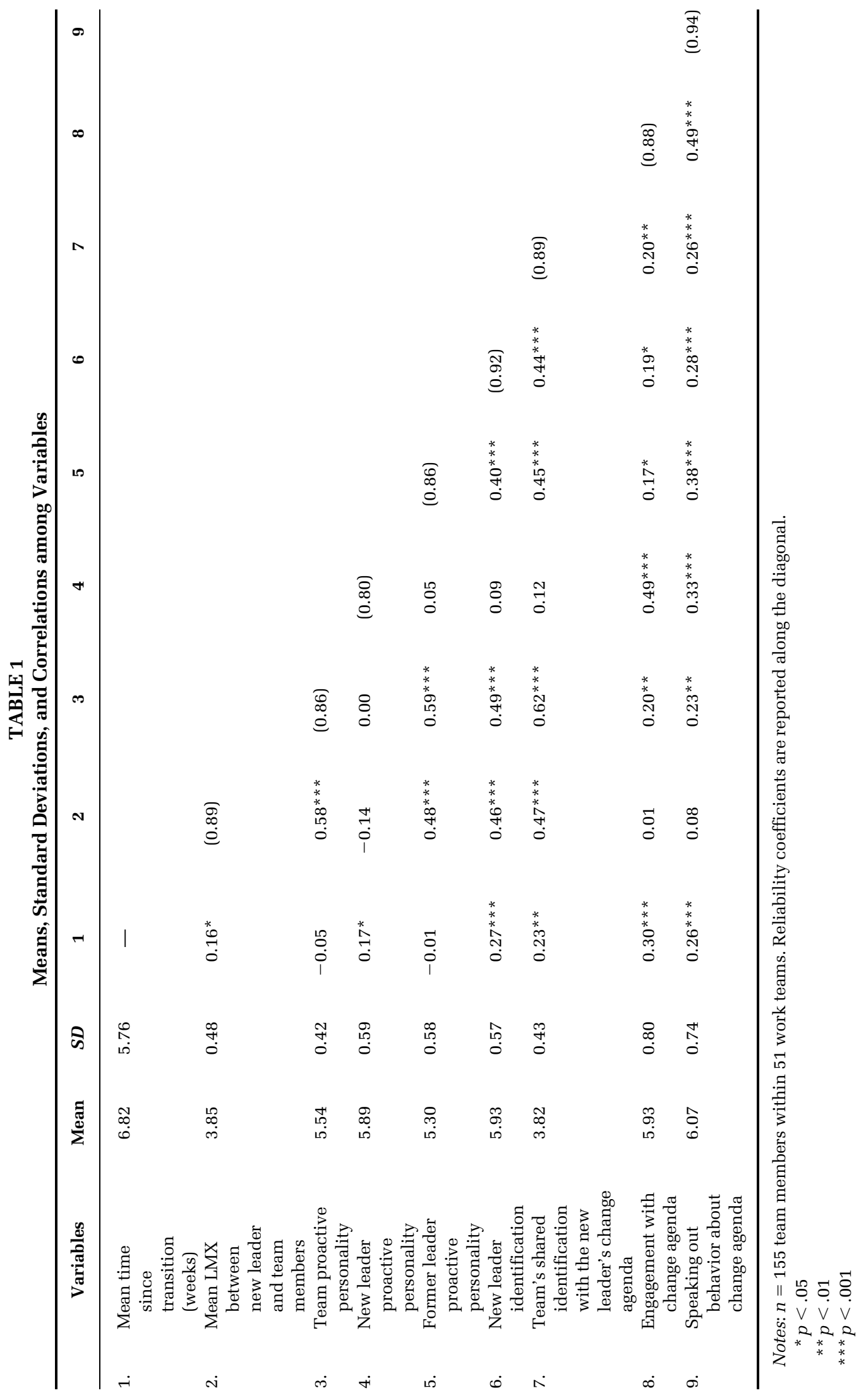


FIGURE 1

Research Model

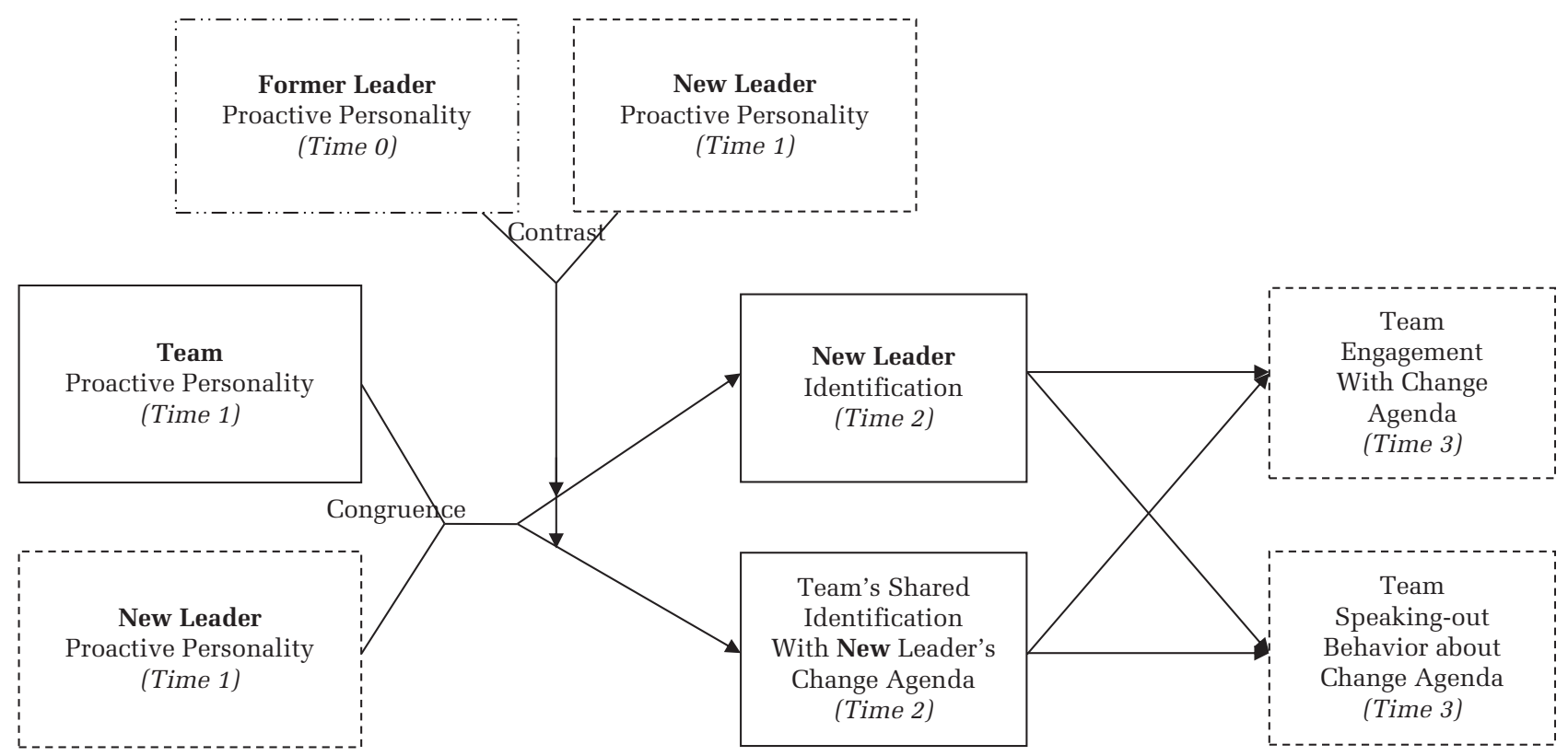

Data sources:

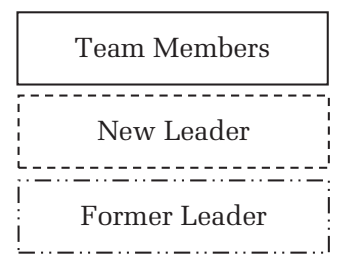

we show in Figures 2 and 3. For new leader identification, Figure 2a shows that when the new leader's proactive personality is stronger than the former leader's proactive personality $(N>F)$, the level of new leader identification is highest if both the team's proactive personality and the new leader's proactive personality are high. Figure $2 b$ shows that when the former leader's proactive personality is greater than the new leader's $(F>N)$, the slope of the surface reflecting the team's proactive personality and its congruence with the new leader's proactive personality indicates that new leader identification is less steep than that when the new leader's proactive personality is higher than the former leader's.

Similarly, in the case of new leader identification and the team's shared identification with the new leader's change agenda, the moderating effect is consistent with our prediction, yielding a surface that is more steeply sloped when the new leader's proactive personality is higher than the former leader's $(N>F)$. These effects are illustrated in Figures 3a and 3b. Specifically, when the new leader is more proactive than the former leader, the highhigh congruence condition between the team's and the new leader's proactive personalities produces the highest level of new leader identification and the team's shared identification with the new leader's change agenda. These patterns offer support for Hypothesis 1 , in which we predicted a congruence effect between the team's and the new leader's proactive personalities on new leader identification and the team's shared identification with the new leader's change agenda. These effects proved significantly stronger when the new leader was more proactive than the former leader.

Next, we tested the moderated mediation hypotheses (Hypotheses 2 and 3) using path analysis 
TABLE 2

Polynomial Regressions of Leader Identification and Team's Shared Identification with New Leader's Change Agendas on Proactive Personality Similarity

\begin{tabular}{|c|c|c|c|c|c|c|c|c|}
\hline & \multicolumn{4}{|c|}{ New Leader Identification } & \multicolumn{4}{|c|}{$\begin{array}{l}\text { Team's Shared Identification with New } \\
\text { Leader's Change Agenda }\end{array}$} \\
\hline & Model 1 & Model 2 & Model 3 & Model 4 & Model 1 & Model 2 & Model 3 & Model 4 \\
\hline Constant & -3.16 & -1.99 & -1.98 & -1.75 & -3.64 & -2.19 & -2.20 & -2.15 \\
\hline Mean time since transition & $0.22^{* *}$ & $0.25 * * *$ & $0.25^{* * *}$ & $0.38^{* * *}$ & $0.15^{*}$ & $0.18^{* *}$ & $0.18^{* *}$ & $.26 * * *$ \\
\hline $\begin{array}{l}\text { Mean LMX between new } \\
\text { leader and team members }\end{array}$ & $0.47^{* * *}$ & $0.26^{* * *}$ & $0.26^{* * *}$ & $0.16^{*}$ & $0.56^{* * *}$ & $0.30^{* * *}$ & $0.30^{* * *}$ & $.24^{* * *}$ \\
\hline$R^{2}$ & \multicolumn{4}{|c|}{$0.29^{* * *}$} & \multicolumn{4}{|c|}{$0.36^{* * *}$} \\
\hline Team proactive personality $(T)$ & & $0.49^{* * *}$ & $0.46^{* * *}$ & -0.08 & & $0.62^{* * *}$ & $0.66^{* * *}$ & .22 \\
\hline $\begin{array}{l}\text { New leader proactive } \\
\text { personality }(N)\end{array}$ & & 0.02 & 0.02 & 0.08 & & 0.07 & 0.07 & .12 \\
\hline$T^{2^{2}}$ & & $0.26^{* *}$ & $0.26^{* *}$ & -0.04 & & $0.30 * * *$ & $0.30 * * *$ & .03 \\
\hline$T \times N$ & & 0.07 & 0.08 & $0.24^{*}$ & & 0.08 & 0.07 & .13 \\
\hline$N^{2}$ & & -0.09 & -0.08 & 0.15 & & -0.03 & -0.04 & $.17^{*}$ \\
\hline$R^{2}$ & \multicolumn{4}{|c|}{$0.45^{* * *}$} & \multicolumn{4}{|c|}{$0.61^{* * *}$} \\
\hline$\Delta R^{2}$ & \multicolumn{4}{|c|}{$0.16^{* * *}$} & \multicolumn{4}{|c|}{$0.26^{* * *}$} \\
\hline $\begin{array}{l}\text { Former leader proactive } \\
\text { personality }(F)\end{array}$ & & & 0.04 & 0.10 & & & -0.06 & -0.20 \\
\hline$R^{2}$ & \multicolumn{4}{|c|}{$0.45^{* * *}$} & \multicolumn{4}{|c|}{$0.61^{* * *}$} \\
\hline$\Delta R^{2}$ & \multicolumn{4}{|c|}{0.00} & \multicolumn{4}{|c|}{0.00} \\
\hline$T \times F$ & & & & 0.22 & & & & $.31^{*}$ \\
\hline$N \times F$ & & & & $-0.47^{* * *}$ & & & & $-.21^{*}$ \\
\hline$T^{2} \times N$ & & & & $0.60^{*}$ & & & & $.56^{*}$ \\
\hline$T^{2} \times F$ & & & & 0.10 & & & & .34 \\
\hline$T \times N^{2}$ & & & & $0.35^{* *}$ & & & & $.22^{*}$ \\
\hline$T \times N \times F$ & & & & $-0.72^{* * *}$ & & & & $-.61^{* * *}$ \\
\hline$N^{3}$ & & & & 0.10 & & & & .03 \\
\hline$N^{2} \times F$ & & & & -0.16 & & & & .13 \\
\hline$R^{2}$ & \multirow{2}{*}{\multicolumn{4}{|c|}{$0.61^{* * *}$}} & \multirow{2}{*}{\multicolumn{4}{|c|}{$0.73^{* * *}$}} \\
\hline$\Delta R^{2}$ & & & & $0.16^{* * *}$ & & & & \\
\hline
\end{tabular}

Notes: $n=155$ team members within 51 work teams. Standardized regression coefficients are reported.

${ }^{*} p<.05$

$* * p<.01$

$* * * p<.001$

conventions to describe the relationships in terms of the direct, indirect, and total effects of the congruence of the new leader's and the team's proactive personalities on the team's engagement with the leader's change agenda and voice behavior, as outlined by Edwards and Lambert (2007). When testing the direct, indirect, and total effects, we employed a bootstrapping-based analysis with 1,000 samples to construct confidence (Duffy, Ganster, Shaw, Johnson, \& Pagon, 2006; Edwards \& Lambert, 2007). In Table 3 we detail the conditions in which the effects of congruence between the new leader's and the team's proactive personalities on engagement with the change agenda and voice behavior differ. New leader identification and the team's shared identification with the new leader's change agenda vary depending on the contrast between the new leader's and former leader's proactive personalities. When the new leader's and the former leader's proactive personalities are incongruent, the indirect effects and total effects are all significant; in contrast, the indirect effects of congruence between the new leader's and team's proactive personalities on their engagement with the new leader's change agenda and their voice behavior are not significant when the new leader's and former leader's proactive personalities are congruent. Thus, the moderated mediations we predicted in Hypotheses 2 and 3 were supported.

\section{DISCUSSION}

Failure to build identification and secure new working relationships during the first few months 
FIGURE 2

Surface Graphs of Similarity between New Leader's and Team's Proactive Personalities Predicting New Leader Identification
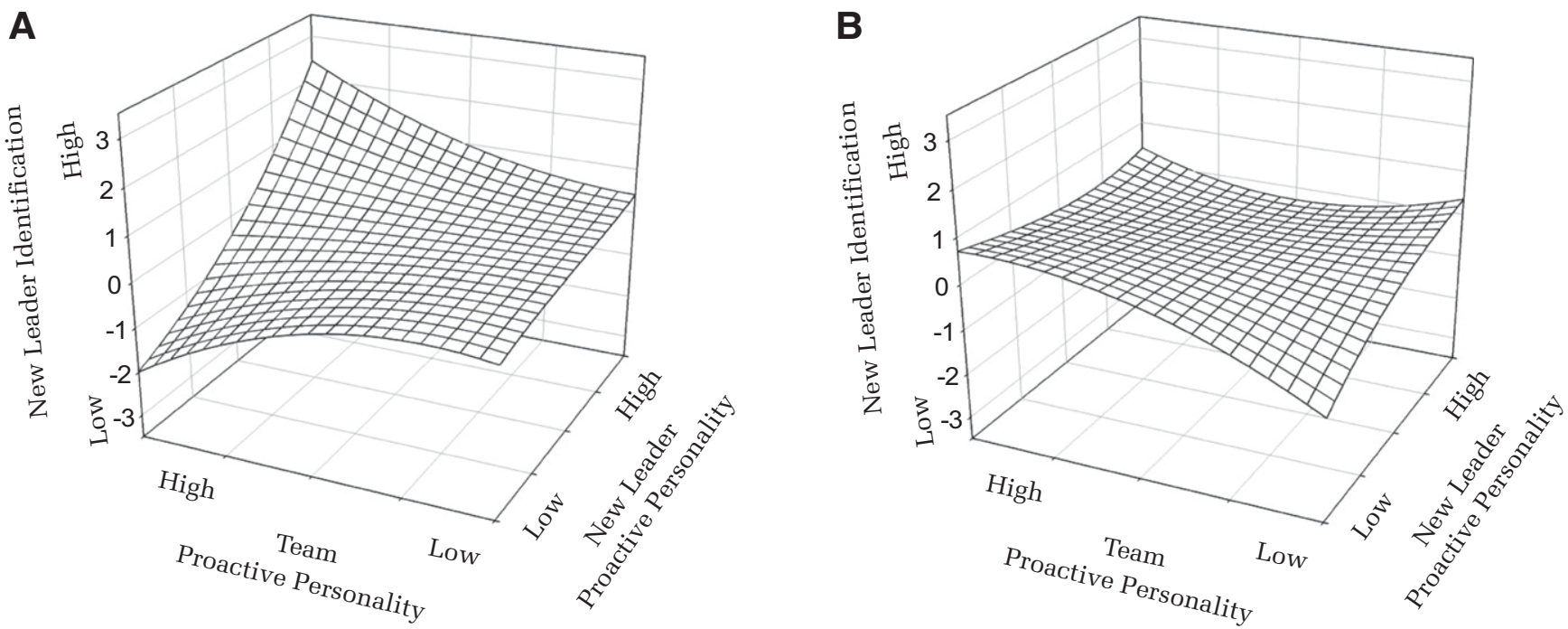

Notes: A) When New Leader's Proactive Personality is Higher than Former Leader's Proactive Personality $(N>F)$, B) When Former Leader's Proactive Personality is Higher than New Leader's Proactive Personality $(F>N)$.

after a new leader transition starts an uphill battle between new leaders and teams (Watkins, 2003). Thus, understanding how new team leaders establish themselves and shape the team's receptiveness to their change agendas is of interest to both scholars and practitioners. In this study, we integrated contrast effects and leader identification to predict determinants that shape teams' receptiveness to a leadership transition. Using three sources-the former leader, the new leader, and the team (members)-over four time periods, we find that congruence between the team's and the new leader's proactive personalities, as well as the contrast between the former and new leaders' proactive personalities interact to predict new leader identification and the team's shared identification with the new leader's change agenda. The congruence effect on new leader identification is stronger if the new leader exhibits a more proactive personality compared to the former leader (i.e., positive contrast), but is weaker when the new leader has a lower level of proactive personality than does the former leader (i.e., negative contrast). New leader identification and the team's shared identification with the new leader's change agenda also serve as mediators between congruence and the two team-level proactive behaviors (i.e., engagement with the change agenda and voice). This mediation effect is stronger in the positive contrast condition but weaker under the negative contrast. These findings suggest that it is not only the congruence between a team's and the new leader's proactive personalities that matters (Zhang et al., 2012), but also the contrast of the new leader's and the former leader's proactive personalities that can enhance new leader identification and the team's shared identification with the new leader's change agenda. Our findings provide insights into how and why congruence is important with respect to a team's engagement and voice about the new leader's change agenda during a leadership transition.

\section{Theoretical Contributions}

Little consensus exists to explain why leadership transitions seem more frequent now than in the past, but substantial evidence suggests that they are disruptive to organizations in general and work teams in particular (Rafferty \& Griffin, 2006; Seo et al., 2012; Van den Bos et al., 2005). Drawing on contrast and leader identification effects, we shed some new light on why and how team members might identify with a new leader. This study also clarifies the mechanisms by which a former leader affects team members' reactions to the new leader's change agenda. Thus, leader transitions can result in proactive behaviors, through leader identification and the team's shared identification with the new leader's change 
FIGURE 3

\section{Surface Graphs of Similarity between New Leader's and Team's Proactive Personalities Predicting Team's Shared Identification with New Leader's Change Agenda}
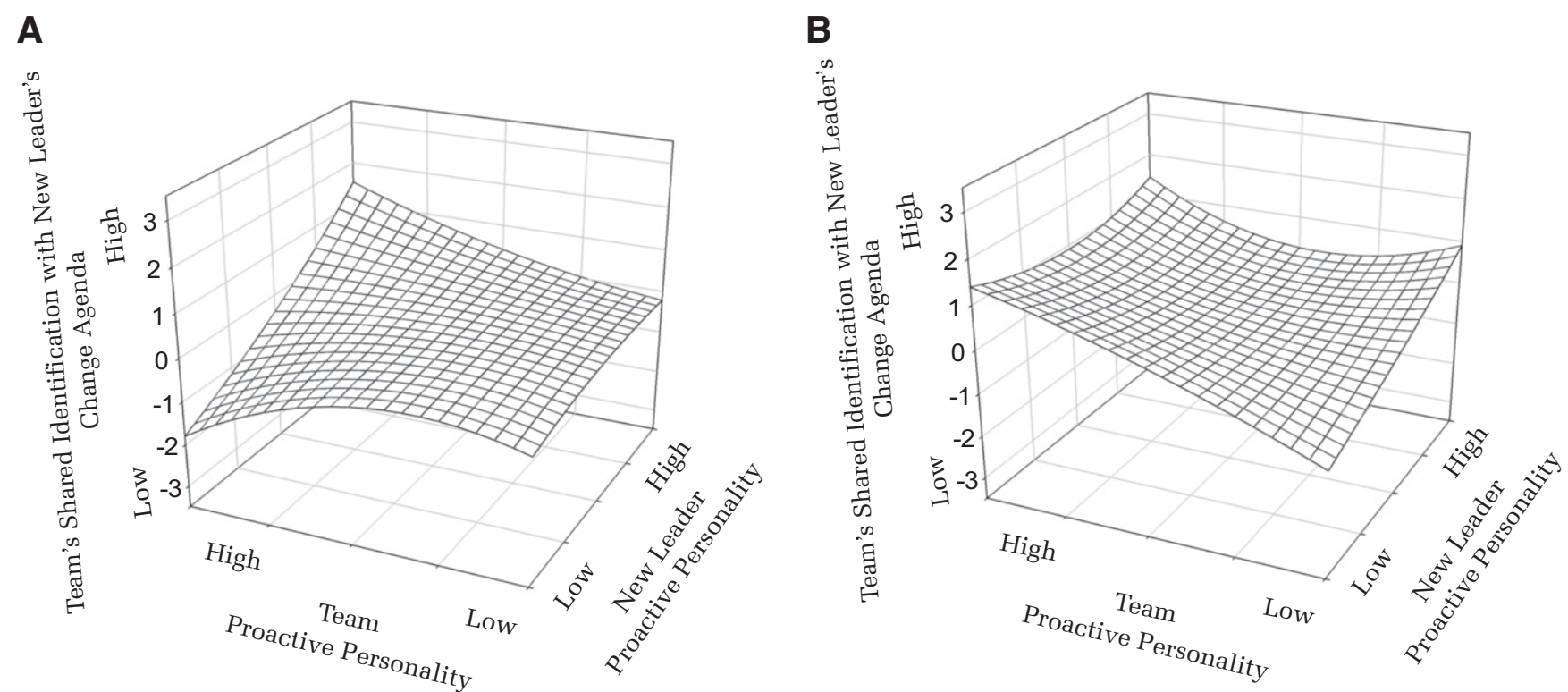

Notes: A) When New Leader's Proactive Personality is Higher than Former Leader's Proactive Personality $(N>F)$, B) When Former Leader's Proactive Personality is Higher than New Leader's Proactive Personality $(F>N)$.

agenda. When there is a positive contrast (i.e., the former leader scores lower than the new leader in proactive personality), team members identify more with and react more positively to the new leader's change agenda. Thus, changes, such as leader transitions, might be more than stressors for employees to cope with (Rafferty \& Griffin, 2006) and instead could offer opportunities for proactivity and even improved work relationships and processes. However, if there is a negative contrast (i.e., the former leader scores higher than the new leader in proactive personality), employee reactions are less positive.

The proactivity literature already has established that a proactive personality leads to positive work outcomes (e.g., Seibert, Crant, \& Kraimer, 1999; Thompson, 2005), and some research has taken a relational perspective to understand the role of proactive personality at work. Li, Liang, and Crant (2010) and Zhang et al. (2012) suggested that the key is not a focal individual's proactive personality but rather the relationship between the leader and team members. Our study contributes further insights by predicting a new, identification-based, mediating mechanism between the new leader and the team. Positive proactive work outcomes result from high levels of leader identification and the team's shared identification with the new leader's change agenda. This identification process is activated by the new leader's entrance and shaped by the contrast with the former leader. At a broader level, our research findings open the door to a new stream of research on leadership transition that suggests the important impact of contrast effects between former and new leaders when it comes to the team's reactions to a new leader.

Finally, this study advances existing leadership research by demonstrating that leader identification and a team's shared identification with a new leader's change agenda is a consequence of the contrast effects between former leaders and new leaders, along with the proactive personality congruence they exhibit with their teams. Our findings explicate the indirect effect of leader identification; it carries through to engagement with and voice about new leaders' change agendas. This novel finding moves beyond existing studies that have aimed to explain successful leadership transitions according to a strategic perspective and focused solely on CEOs or top management transitions (e.g., Cannella \& Shen, 2001; Giambatista et al., 2005; Graffin et al., 2011, 2013; Shen \& Cannella, 2002; Zhang \& Rajagopalan, 2003). By investigating newly transitioned middleand lower-level leaders, as well as team members' 


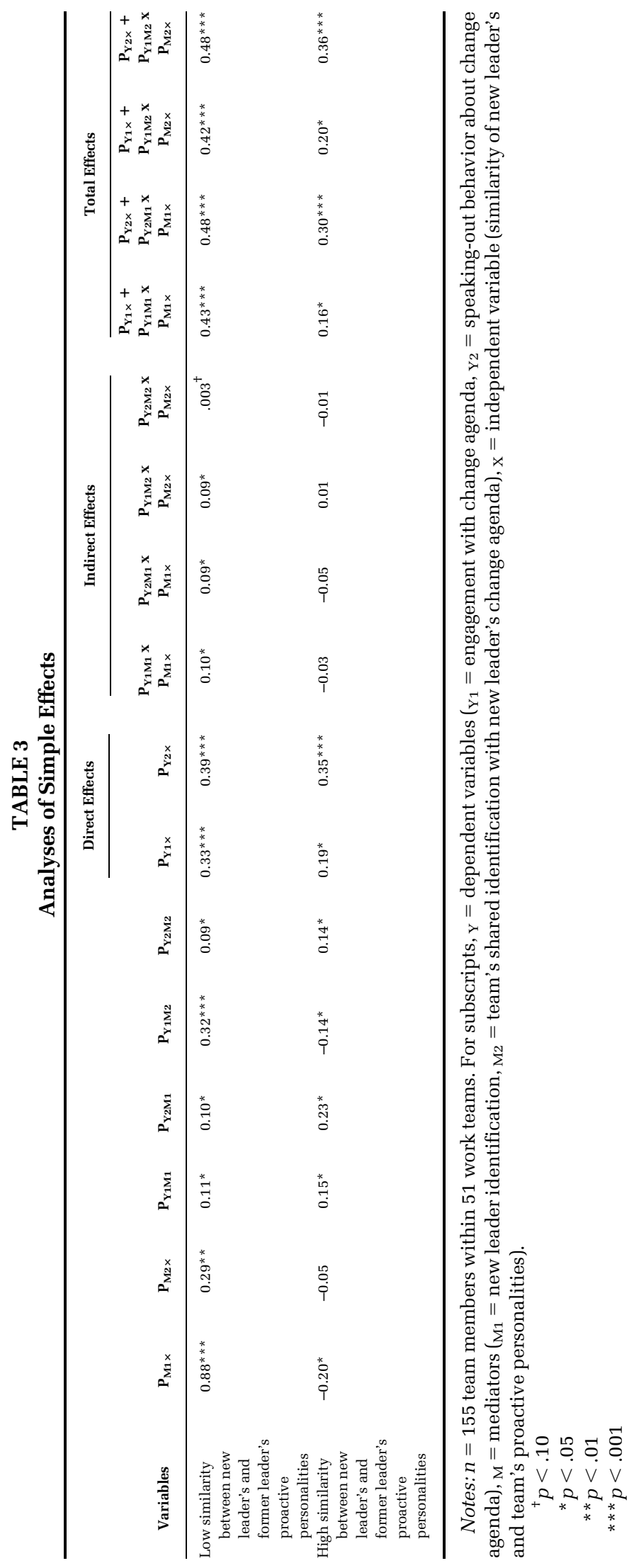


reactions to the leadership transition, we shed light on the mechanisms that help determine how and why congruence in proactive personalities may prompt negative or positive consequences, and thus offer suggestions for designing more effective leadership transitions.

\section{Practical Implications}

The results have implications for practitioners as well. It is not solely the congruence between a new leader and the team that counts. Rather, in the context of a leadership transition, the contrast between the new leader's and the former leader's proactive personalities must be taken into account as well. Organizations should recognize the advantages of selecting a new leader who is more proactive and change-oriented than a former leader, and in turn can produce an effective leadership transition, with minimal disruption, that helps new leaders achieve their change agendas. If the former leader led the team in a passive manner, the selection of a new, proactive leader would greatly enhance the team's receptiveness to the transition when the team is also proactive. In this scenario, the former leader might not have affected the team's experience of a change in leadership substantially, but the congruence between the team's and the new leader's proactive personalities can motivate the team's engagement with, and voice behaviors toward, the new leader's change agenda. Organizations also could provide training to help newly appointed leaders demonstrate and emphasize their unique, positive, proactive characteristics to their teams. This uniqueness can help new leaders establish themselves in new positions, soon after the transition occurs.

\section{Limitations and Research Directions}

The findings of the present study should be considered in light of several limitations, each of which might be addressed through further research. The first limitation pertains to the extent to which our theories and results generalize to other cultural populations; our data were collected only in China. Proactive personality levels may vary across cultures (e.g., Claes, Beheydt, \& Lemmens, 2005). Hall (1976) categorized China as a high-context culture, where people base their communication largely on personal observations and interpretations. Members of this culture tend to pay close attention to maintaining harmony, and hesitate to take actions to influence their environments. Thus, weaker congruence might appear in cultures with low power distance and relationship orientation scores. Additional research could address this limitation by comparing findings based on data from both high- and low-context cultures.

With our focus on proactive personality in a change context, this study also measured only proactive personalities across the leaders and teams; we thus cannot rule out alternative explanations for our results that might stem from other relevant characteristics. Some alternative trait-related variables might include psychological resilience, openness to change, perspective taking, or political skills, all of which have been identified as highly relevant for leadership transitions and organizational change (e.g., Ferris \& Treadway, 2012; Humphrey, 2002; Shin et al., 2012; Wanberg \& Banas, 2000). It would be interesting to investigate in further studies whether congruence across other traits affects leadership transitions.

Our research context, involving a leadership transition, implies a work environment that can be uncertain, complex, and challenging. In a dynamic work environment, employees must be more proactive to anticipate and act on threats and opportunities (Griffin, Neal, \& Parker, 2007; Leana, Appelbaum, \& Shevchuk, 2009). New leaders face challenging tasks when they take charge of new teams (Sauer, 2011), so they may be particularly open to coordinating efforts and activities that promise to improve work processes (Wu \& Wang, 2011). Unlike passive leaders who only take leadership roles when required or assigned to do so, highly proactive leaders likely induce purposeful changes in the team. For example, proactive new leaders seek to determine how best to guide their teams (Sauer, 2011). Being oriented toward improving the circumstances after the transition, they actively think about what they can do to improve the status quo, as left by the previous leader, and bring about a better future for the team (Crossley, Cooper, \& Wernsing, 2013). Thus, congruence between the new leader's and the team's proactive personalities is necessary and important in the present research context.

Complementary benefits for team performance similarly might emerge if employees are not proactive and fall under the supervision of an extroverted leader, or when employees are proactive but work with a less extroverted leader, especially if those leaders are in charge of groups that are responsible for structured, repetitive, or effort-based tasks (Grant, Gino, \& Hofmann, 2011). Judge, Piccolo, 
and Kosalka (2009) noted that extroverted leaders tend to behave in dominant, aggressive, and grandiose ways. In a routine work environment, extroverted leaders may reject employees' proactive ideas in favor of their own practices, to signal their standing and authority (Grant et al., 2011). Although this phenomenon seems likely in a routine work climate, further research should examine whether new leader-team congruence or incongruence in proactive personalities also matters in a routine work context.

A further challenge is the conceptualization and assessment of proactivity. Within the proactivity framework proposed by Parker, Bindl, and Strauss (2010), we focus on proactive personality rather than proactive behavior, which refers to self-initiated, anticipatory action that aims to change and improve the situation or oneself (Grant \& Ashford, 2008; Parker et al., 2006). That is, a personality-based approach assumes individuals are proactive across multiple contexts and over time, regardless of the contingencies of a situation (Parker et al., 2010). A proactive personality emphasizes taking control and bringing about change, so it might predict multiple proactive behaviors across different domains (e.g., see meta-analyses by Fuller \& Marler, 2009; Parker \& Collins, 2010). Building on this definition, Bateman and Crant (1993) developed a 17-item scale to access proactive personality that Seibert et al. (2001) later shortened to a 10-item scale and validated. We used this scale, as it is typically regarded as "good proactivity." However, proactive behavior is not always appreciated; it can sometimes be regarded as "bad proactivity" (for details, see Burris, 2012; Fuller, Marler, Hester, \& Otondo, 2015; Grant, Parker, \& Collins, 2009; Lam, Peng, Wong, \& Lau, 2015). In some situations, a proactive team might face a proactive new leader but find the situation untenable if the leader intentionally guides the team with bad proactivity. Additional studies that consider the various natures or meanings of proactivity in the workplace may contribute to our understanding of congruence in leader-team proactivity.

\section{CONCLUSION}

The present study represents an initial attempt to explore contrast effects between former and new leaders and their influence on the effects of the congruence between the team's and new leader's proactive personalities. We explore how new leader identification and team's shared identification with the new leader's change agenda develops due to the contrasts between former and new leaders and results in the team's behavioral responses, such as engagement and voice, that support the leader and his or her change agenda while also enabling a more effective leadership transition. Many factors contribute to failed organizational efforts, so scholars and practitioners increasingly seek to identify factors leading to (in)effective leadership transitions. The present study offers some new insights, as well as avenues for further investigations in this field.

\section{REFERENCES}

Andersen, S. M., \& Chen, S. 2002. The relational self: An interpersonal social-cognitive theory. Psychological Review, 109: 619-645.

Ang, J., Lauterbach, B., \& Vu, J. 2003. Efficient labor and capital markets: Evidence from CEO appointments. Financial Management, 32: 27-52.

Annual Report of China Inbound Tourism Development. 2015. Beijing: Beijing Tourism Education Press.

Bagozzi, R. P., \& Edwards, J. R. 1998. A general approach for representing constructs in organizational research. Organizational Research Methods, 1: 45-87.

Ballinger, G. A., \& Marcel, J. J. 2010. The use of an interim CEO during succession episodes and firm performance. Strategic Management Journal, 31: 262-283.

Ballinger, G. A., \& Schoorman, F. D. 2007. Individual reactions to leadership succession in workgroups. Academy of Management Review, 32: 118-136.

Ballinger, G. A., Schoorman, F. D., \& Lehman, D. W. 2009. Will you trust your new boss? The role of affective reactions to leadership succession. The Leadership Quarterly, 20: 219-232.

Bandalos, D. L. 2002. The effects of item parceling on goodness-of-fit and parameter estimate bias in structural equation modeling. Structural Equation Modeling, 9: 78-102.

Bandalos, D. L., \& Finney, S. J. 2001. Item parceling issues in structural equation modeling. In G. A. Marcoulides, \& R. E. Schumacker (Eds.), New developments and techniques in structural equation modeling: 269-296. Hillsdale, NJ: Lawrence Erlbaum Associates.

Bateman, T. S., \& Crant, J. M. 1993. The proactive component of organizational behavior: A measure and correlates. Journal of Organizational Behavior, 14: 103-118.

Bliese, P. D. 2000. Within-group agreement, nonindependence, and reliability: Implications for data aggregation and analysis. In K. J. Klein, \& S. W. Kozlowski (Eds.), Multilevel theory, research, and methods in organizations: 349-381. San Francisco, CA: Jossey-Bass.

Brislin, R., Lonner, W. J., \& Thorndike, R. 1973. Crosscultural research methods. New York, NY: Wiley. 
Brown, D. J., Cober, R. T., Kane, K., Levy, P. E., \& Shalhoop, J. 2006. Proactive personality and the successful job search: A field investigation with college graduates. The Journal of Applied Psychology, 91: 717-726.

Burris, E. R. 2012. The risks and rewards of speaking up: Managerial responses to employee voice. Academy of Management Journal, 55: 851-875.

Cannella, A. A., \& Shen, W. 2001. So close and yet so far: Promotion versus exit for CEO heirs apparent. Academy of Management Journal, 44: 252-270.

Chan, D. 1998. Functional relations among constructs in the same content domain at different levels of analysis: A typology of composition models. The Journal of Applied Psychology, 83: 234-246.

Claes, R., Beheydt, C., \& Lemmens, B. 2005. Unidimensionality of abbreviated proactive personality scales across cultures. Applied Psychology, 54: 476-489.

Cole, M. S., Carter, M. Z., \& Zhang, Z. 2013. Leader-team congruence in power distance values and team effectiveness: The mediating role of procedural justice climate. The Journal of Applied Psychology, 98: 962-973.

Crossley, C. D., Cooper, C. D., \& Wernsing, T. S. 2013. Making things happen through challenging goals: Leader proactivity, trust, and business-unit performance. The Journal of Applied Psychology, 98: 540-549.

Demo, D. H. 1992. The self-concept over time: Research issues and directions. Annual Review of Sociology, 18: 303-326.

Duffy, M. K., Ganster, D. C., Shaw, J. D., Johnson, J. L., \& Pagon, M. 2006. The social context of undermining behavior at work. Organizational Behavior and Human Decision Processes, 101: 105-126.

Edwards, J. R. 2002. Alternatives to difference scores: Polynomial regression analysis and response surface methodology. In F. Drasgow, \& N. W. Schmitt (Eds.), Advances in measurement and data analysis: 350-400. San Francisco, CA: Jossey-Bass.

Edwards, J. R., \& Lambert, L. S. 2007. Methods for integrating moderation and mediation: A general analytical framework using moderated path analysis. Psychological Methods, 12: 1-22.

Edwards, J. R., \& Parry, M. E. 1993. On the use of polynomial regression equations as an alternative to difference scores in organizational research. Academy of Management Journal, 36: 1577-1613.

Ferris, G. R., \& Treadway, D. C. 2012. Politics in organizations: History, construct specification, and research directions. In G. R. Ferris \& D. C. Treadway (Eds.), Politics in organizations: Theory and research considerations. New York, NY: Taylor \& Francis Group.
Frederick, S., \& Loewenstein, G. 1999. Hedonic adaptation. In D. Kahneman, E. Diener, \& N. Schwarz (Eds.), Wellbeing: The foundations of hedonic psychology: 302-329. New York, NY: Russell Sage Foundation.

Fugate, M., \& Kinicki, A. J. 2008. A dispositional approach to employability: Development of a measure and test of implications for employee reactions to organizational change. Journal of Occupational and Organizational Psychology, 81: 503-527.

Fuller, B., Marler, L. E., Hester, K., \& Otondo, R. F. 2015. Leader reactions to follower proactive behavior: Giving credit when credit is due. Human Relations, 68: 879-898.

Fuller, J. B., \& Marler, L. E. 2009. Change driven by nature: A meta-analytic review of the proactive personality literature. Journal of Vocational Behavior, 75: 329-345.

Giambatista, R. C., Rowe, W. G., \& Riza, S. 2005. Nothing succeeds like succession: A critical review of leader succession literature since 1994. The Leadership Quarterly, 16: 963-991.

Goodman, J. S., \& Blum, T. C. 1996. Assessing the nonrandom sampling effects of subject attrition in longitudinal research. Journal of Management, 22: 627-652.

Graffin, S. D., Boivie, S., \& Carpenter, M. A. 2013. Examining CEO succession and the role of heuristics in early-stage CEO evaluation. Strategic Management Journal, 34: 383-403.

Graffin, S. D., Carpenter, M. A., \& Boivie, S. 2011. What's all that (strategic) noise? Anticipatory impression management in CEO succession. Strategic Management Journal, 32: 748-770.

Grant, A. M., \& Ashford, S. J. 2008. The dynamics of proactivity at work. Research in Organizational Behavior, 28: 3-34.

Grant, A. M., Gino, F., \& Hofmann, D. A. 2011. Reversing the extraverted leadership advantage: The role of employee proactivity. Academy of Management Journal, 54: 528-550.

Grant, A. M., Parker, S., \& Collins, C. 2009. Getting credit for proactive behaviors: Supervisor reactions depend on what you value and how you feel. Personnel Psychology, 62: 31-55.

Griffin, M. A., Neal, A., \& Parker, S. K. 2007. A new model of work role performance: Positive behavior in uncertain and interdependent contexts. Academy of Management Journal, 50: 327-347.

Hall, E. T. 1976. Beyond Culture. Garden City, NY: Doubleday \& Company.

Herscovitch, L., \& Meyer, J. P. 2002. Commitment to organizational change: Extension of a three-component model. The Journal of Applied Psychology, 87: 474-487. 
Hobman, E. V., Jackson, C. J., Jimmieson, N. L., \& Martin, R. 2011. The effects of transformational leadership behaviours on follower outcomes: An identity-based analysis. European Journal of Work and Organizational Psychology, 20: 553-580.

Humphrey, R. H. 2002. The many faces of emotional leadership. The Leadership Quarterly, 13: 493-504.

Huson, M. R., Malatesta, P. H., \& Parrino, R. 2004. Managerial succession and firm performance. Journal of Financial Economics, 74: 237-275.

Huy, Q. N. 2002. Emotional balancing of organizational continuity and radical change: The contribution of middle managers. Administrative Science Quarterly, 47: 31-69.

Jansen, K. J., \& Kristof-Brown, A. L. 2005. Marching to the beat of a different drummer: Examining the impact of pacing congruence. Organizational Behavior and Human Decision Processes, 97: 93-105.

Judge, T. A., Piccolo, R. F., \& Kosalka, T. 2009. The bright and dark sides of leader traits: A review and theoretical extension of the leader trait paradigm. The Leadership Quarterly, 20: 855-875.

Kahn, W. A. 1990. Psychological conditions of personal engagement and disengagement at work. Academy of Management Journal, 33: 692-724.

Kark, R., Shamir, B., \& Chen, G. 2003. The two faces of transformational leadership: Empowerment and dependency. The Journal of Applied Psychology, 88: 246-255.

Lam, L. W., Peng, K. Z., Wong, C.-S., \& Lau, D. C. 2015. Is more feedback seeking always better? Leader-member exchange moderates the relationship between feedback-seeking behavior and performance. Journal of Management, 43: 2195-2217.

Lam, W., \& Chen, Z. 2011. When I put on my service mask: Determinants and outcomes of emotional labor among hotel service providers according to affective event theory. International Journal of Hospitality Management, 31: 3-11.

Lance, C. E., Vandenberg, R. J., \& Self, R. M. 2000. Latent growth models of individual change: The case of newcomer adjustment. Organizational Behavior and Human Decision Processes, 83: 107-140.

Leana, C., Appelbaum, E., \& Shevchuk, I. 2009. Work process and quality of care in early childhood education: The role of job crafting. Academy of Management Journal, 52: 1169-1192.

Lester, S. W., Meglino, B. M., \& Korsgaard, M. A. 2002. The antecedents and consequences of group potency: A longitudinal investigation of newly formed work groups. Academy of Management Journal, 45: 352-368.
Li, N., Liang, J., \& Crant, J. M. 2010. The role of proactive personality in job satisfaction and organizational citizenship behavior: A relational perspective. The Journal of Applied Psychology, 95: 395-404.

Major, D. A., Turner, J. E., \& Fletcher, T. D. 2006. Linking proactive personality and the Big Five to motivation to learn and development activity. The Journal of Applied Psychology, 91: 927-935.

Markman, K. D., \& McMullen, M. N. 2003. A reflection and evaluation model of comparative thinking. Personality and Social Psychology Review, 7: 244-267.

Markus, H., \& Wurf, E. 1987. The dynamic self-concept: A social psychological perspective. Annual Review of Psychology, 38: 299-337.

Neff, T. J., \& Citrin, J. M. 2005. You're in charge: Now what? New York, NY: Crown Business.

Parker, S. K., Bindl, U. K., \& Strauss, K. 2010. Making things happen: A model of proactive motivation. Journal of Management, 36: 827-856.

Parker, S. K., \& Collins, C. G. 2010. Taking stock: Integrating and differentiating multiple proactive behaviors. Journal of Management, 36: 633-662.

Parker, S. K., Williams, H. M., \& Turner, N. 2006. Modeling the antecedents of proactive behavior at work. The Journal of Applied Psychology, 91: 636-652.

Rafferty, A. E., \& Griffin, M. A. 2006. Perceptions of organizational change: A stress and coping perspective. The Journal of Applied Psychology, 91: 1154-1162.

Rich, B. L., Lepine, J. A., \& Crawford, E. R. 2010. Job engagement: Antecedents and effects on job performance. Academy of Management Journal, 53: 617-635.

Ritter, B. A., \& Lord, R. G. 2007. The impact of previous leaders on the evaluation of new leaders: An alternative to prototype matching. The Journal of Applied Psychology, 92: 1683-1695.

Sauer, S. J. 2011. Taking the reins: The effects of new leader status and leadership style on team performance. The Journal of Applied Psychology, 96: 574-587.

Schwarz, N., \& Bless, H. 1992. Constructing reality and its alternatives: An inclusion/exclusion model of assimilation and contrast effects in social judgment. In L. L. Martin, \& A. Tesser (Eds.), The construction of social judgments: 217-247. Mahwah, NJ: Lawrence Erlbaum Associates.

Seibert, S. E., Crant, J. M., \& Kraimer, M. L. 1999. Proactive personality and career success. The Journal of Applied Psychology, 84: 416-427.

Seibert, S. E., Kraimer, M. L., \& Crant, J. M. 2001. What do proactive people do? A longitudinal model linking proactive personality and career success. Personnel Psychology, 54: 845-874. 
Seo, M. G., Taylor, S. M., Hill, N. S., Zhang, X., Tesluk, P., \& Lorinkova, N. M. 2012. The role of affect and leadership during organizational change. Personnel Psychology, 65: 121-165.

Shamir, B., Zakay, E., Breinin, E., \& Popper, M. 1998. Correlates of charismatic leader behavior in military units: Subordinates' attitudes, unit characteristics, and superiors' appraisals of leader performance. Academy of Management Journal, 41: 387-409.

Shen, W., \& Cannella, A. A. 2002. Revisiting the performance consequences of CEO succession: The impacts of successor type, postsuccession senior executive turnover, and departing CEO tenure. Academy of Management Journal, 45: 717-733.

Shen, W., \& Cannella, A. A. 2003. Will succession planning increase shareholder wealth? Evidence from investor reactions to relay CEO successions. Strategic Management Journal, 24: 191-198.

Shin, J., Taylor, S. M., \& Seo, M. G. 2012. Resources for change: The relationships of organizational inducements and psychological resilience to employees' attitudes and behaviors toward organizational change. Academy of Management Journal, 55: 727-748.

Srull, T. K., \& Wyer, R. S. 1989. Person memory and judgement. Psychological Review, 96: 58-83.

Thompson, J. A. 2005. Proactive personality and job performance: A social capital perspective. The Journal of Applied Psychology, 90: 1011-1017.

Tversky, A., \& Griffin, D. 1991. Endowment and contrast in judgments of well-being. In F. Strack, M. Argyle, \& N. Schwarz (Eds.), Subjective well-being: An interdisciplinary perspective: 101-118. Oxford, U.K.: Pergamon Press.

Van den Bos, K., Burrows, J. W., Umphress, E., Folger, R., Lavelle, J. J., Eaglestone, J., \& Gee, J. 2005. Prior experiences as temporal frames of reference in social justice: The influence of previous fairness experiences on reactions to new and old supervisors. Social Justice Research, 18: 99-120.

Van Dyne, L., \& LePine, J. A. 1998. Helping and voice extra-role behaviors: Evidence of construct and predictive validity. Academy of Management Journal, 41: 108-119.

van Knippenberg, D., van Knippenberg, B., De Cremer, D., \& Hogg, M. A. 2004. Leadership, self, and identity: A review and research agenda. The Leadership Quarterly, 15: 825-856.

Wanberg, C. R., \& Banas, J. T. 2000. Predictors and outcomes of openness to changes in a reorganizing workplace. The Journal of Applied Psychology, 85: 132-142.

Watkins, M. 2003. The first 90 days: Critical success strategies for new leaders at all levels. Boston, MA: Harvard Business School Press.
Watkins, M. D. 2009. Picking the right transition strategy. Harvard Business Review, 87: 46-53.

Wu, C.-H., \& Wang, Y. 2011. Understanding proactive leadership. In W. H. Mobley, M. Li, \& Y. Wang (Eds.), Advances in global leadership: 299-314. Bingley, U.K.: Emerald Group Publishing.

Zhang, Y. 2008. Information asymmetry and the dismissal of newly appointed CEOs: an empirical investigation. Strategic Management Journal, 29: 859-872.

Zhang, Y., \& Rajagopalan, N. 2003. Explaining new CEO origin: Firm versus industry antecedents. Academy of Management Journal, 46: 327-338.

Zhang, Z., Wang, M., \& Shi, J. 2012. Leader-follower congruence in proactive personality and work outcomes: The mediating role of leader-member exchange. Academy of Management Journal, 55: 111-130.

Zhao, H. H., Seibert, S. E., Taylor, M. S., Lee, C., \& Lam, W. 2016. Not even the past: The joint influence of former leader and new leader during leader succession in the midst of organizational change. The Journal of Applied Psychology, 101: 1730-1738.

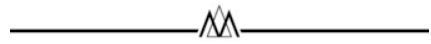

Wing Lam (wing.lam@polyu.edu.hk) is an associate professor in the Faculty of Business at the Hong Kong Polytechnic University. She received her $\mathrm{PhD}$ from the same university. Her research interests focus on proactivity, leadership, and emotional labor.

Cynthia Lee (c.lee@northeastern.edu) is a full professor in the D'Amore-McKim School of Business, Northeastern University. She holds a PhD from the University of Maryland at College Park. Her research focuses on employment relationships and proactivity.

M. Susan Taylor (staylor@rhsmith.umd.edu) is a professor of human resources and organizational change at the Robert H. Smith School of Business, the University of Maryland at College Park. Her research interests include episodic and continuous change, the intersect of organizational justice, psychological contracts, and human resource programs, and the role of negotiation in organizational change.

Helen H. Zhao (hhzhao@hku.hk) is an assistant professor in the Faculty of Business and Economics at University of Hong Kong. She received her PhD from University of Iowa. Her research interests include leader succession, time, and social networks. 
Copyright of Academy of Management Journal is the property of Academy of Management and its content may not be copied or emailed to multiple sites or posted to a listserv without the copyright holder's express written permission. However, users may print, download, or email articles for individual use. 